\title{
Keunikan Nama-Nama Geografi Indonesia: Dari Nama Generik ke Spesifik
}

\author{
Abdul Gaffar Ruskhan \\ Badan Pengembangan dan Pembinaan Bahasa
}

\begin{abstract}
Abstrak: Nama-nama geografi di Indonesia memiliki bentuk yang bermacam-macam, baik yang berasal dari bahasa Indonesia maupun yang berasal dari bahasa daerah masing-masing. Keberbagaian itu merupakan keunikan nama geografi yang kaya dengan budaya bangsa, termasuk bahasanya. Suatu hal yang tidak dapat dibantah bahwa terdapat pula nama geografi yang berasal dari bahasa asing. Namun, penggunaan bahasa daerah dan bahasa Indonesia sebagai nama geografi merupakan pilihan yang tidak dapat diabaikan. Dalam nama geografi, ada unsur generik dan unsur spesifik yang menjadi hal yang penting. Unsur generik itu merupakan unsur yang mengandung makna umum berupa kenampakan alam, seperti daratan dan perairan, serta. kawasan khusus, buatan, dan administratif. Sementara itu, nama spesifiknya adalah nama yang membatasi unsur generiknya. Unsur spesifik itu muncul dari penamaan masyarakatnya, yang tidak lepas dari nama generiknya. Masing-masing memiliki aspek historisnya.
\end{abstract}

Kata kunci: nama geografi, unsur generik, dan unsur spesifik

\begin{abstract}
The Indonesian geographical names are various in terms of its origins language. The are many geographical names are derived from the national language (Indonesian) and the local languages. The diversities are the uniqueness that are rich with ethnicity and culture, including languages. The geographical names are consisting of the generic names and specific names. The generic names are the names that applied in general, either associated with the natural appearance, artificial area, or administration area. The generic names are potentially derived both from the national language (Indonesian) and from the local languages. Their use makes them became specific. However, there are many specific names in the form of the generic elements only. Many names that people who have created can not be separated from the history of the names.
\end{abstract}

Key words: geographical names, generic factor, and specific factor

\section{Latar Belakang dan Masalah}

Indonesia kaya dengan nama geografi. Kekayaan itu menjadi keunggulan budaya Indonesia. Di samping nama-nama geografi yang berasal dari bahasa Indonesia, banyak juga yang berasal dari bahasa daerah. Sebagaimana diketahui, ada 736 bahasa daerah di Indonesia yang semuanya memberikan sumbangan yang berarti terhadap nama geografi di Indonesia.

Sebuah nama, menurut Plato sebagaimana dikutip Pateda (2001), memiliki hubungan hayati dengan benda. Namun, ia pun mempertanyakan apakah pemberian nama terhadap suatu benda didasarkan atas kesewengan seseorang atau kelompok atau didasarkan atas penjanjian bersama. Jika berbicara tentang nama, hal itu tentu tidak lepas dari pembicaraan tentang lambang dan makna. Lambang adalah label terhadap kata dalam suatu bahasa, sedangkan makna adalah objek yang kita hayati di dunia nyata berupa acuan yang ditunjukkan lambang tersebut. Dengan demikian, kata dapat disebut sebagai sebuah benda yang menjadi label dari setiap benda itu.

Lebih lanjut, Aristoteles (dalam Pateda, 2001) menyebutkan bahwa nama harus sesuai dengan acuan yang diberi nama itu. Menurutnya, penamaan adalah perjanjian atau konvensi. Penamaan itu bersumber dari berbagai kalangan seperti pakar, penulis, pengarang, wartawan, dan tokoh masyarakat.

Berkaitan dengan penamaan geografi, timbul pertanyaan apakah penamaan itu muncul secara tiba-tiba atau ada kesepakatan di kalangan 
masyarakat. Oleh karena itu, penamaan geografi dapat dikaitkan dengan mengapa masyarakat menamakan suatu nama geografi dengan sesuatu. Misalnya, Bukit Barisan merupakan barisan bukit di sepanjang Pulau Sumatra. Begitu pula nama spesifik yang mengandung nama generik, seperti Bukittinggi dan Kotabaru merupakan nama kota yang terdiri atas nama generik yang membentuk nama spesifik. Jika kita mengatakan bukit, nama itu adalah generik yang terdapat pada Bukittinggi. Posisi kotanya terletak di daerah ketinggian seperti bukit sehingga dinamakan Bukittinggi. Sementara itu, Kotabaru merupakan kota yang dibangun lebih akhir sehingga dinamakan Kotabaru. Begitu pula nama Kebonkacang, Kebonmanggis, dan Kebon rambutan tentu ada kaitan generik kebon (kebun) sebagai lahan yang ditanami pohon tertentu. Begitu diikuti nama jenis pohon sebagai spesifik, nama untuk geografi itu akan menjadi spesifik pula. Kebonkacang, Kebonmanggis, dan Kebonrambutan menjadi nama geografi yang masing-masing adalah nama spesifik di Jakarta.

Kita memahami keragaman etnis dan bahasa di Indonesia sehingga memberikan pengaruh besar terhadap penamaan geografi Indonesia. Keragaman itu memberikan pemahaman terhadap latar budaya masyarakatnya. Misalnya, di Sumatra Barat banyak ditemukan nama geografi yang menggunakan angka, misalnya Situjuh, Ampekkoto, Limapuluh Koto, Kambing tujuh, Limakaum, Tigobaleh, Tigakampung, dan Kelok Ampekpuluh Ampek. Hal itu menggambarkan bahwa masyarakat Minangkabau lebih terbiasa dan mudah menggunakan angka-angka (metematis) dalam mengukur sesuatu, biasanya diwujudkan dengan perniagaan.

Lain lagi nama geografi di Jawa Barat yang lebih akrab dengan air (ci) sehingga nama-nama geografi lebih banyak menggunakan ci. Misalnya, Cianjur, Ciamis, Cipanas, Cirankjang, Cimacan, Cibogo, Cipayung, Cileduk, dan Cikoneng. Di Jakarta, misalnya, karena dahulu daerah ini terdiri atas rawa-rawa dan kebun, nama-nama geografi pun menggambarkan keadaan daerah itu. Misalnya, Rawamangun, Rawabuaya, Rawabadak, Rawakemiri, Rawabangke, dan Rawabelong serta Kebonjeruk, Kebonnanas, Kebonsirih, Kebonkopi, Kebonmanggis, dan Kebonkacang. Walaupun zaman sudah berubah, nama-nama itu masih tetap bertahan sampai sekarang. Memang ada upaya sebagian pengembang yang ingin perumahannya di-pandang bergengsi menamakan perumahannya dengan nama keinggris-inggrisan. Misalnya, Pedurenan di Ciledug, Kota Tangerang diganti dengan Duren Village. Dengan adanya nama Duren Village, Pedurenan masih ada sebagai nama diar kompleks itu.

Penamaan geografi yang akan dibicarakan yaitu nama geografi yang berupa gabungan kata (frase). Nama yang pertama berasal dari nama generik geografi, sedangkan yang berikut-nya adalah nama spesifik sehingga penggabungan itu membentuk nama itu menjadi spesifik.

Penamaan geografi di Indonesia tampaknya memiliki keteraturan. Nama-nama geografi itu ada yang berbahasa Indonesia, berbahasa daerah, bahkan ada yang berbahasa asing. Pembakuan nama-nama geografi itu harus memperhatikan keragaman bahasa yang menjadi sarana nama geografi itu. Jika nama-nama itu harus ditundukkan ke dalam kaidah bahasa Indonesia, banyak nama yang terlalu sulit diindonesiakan. Karena itu, salah satu pinsip, yakni mempertahankan nama lokal merupakan jalan terbaik untuk mengukuhkan nama lokal ke tingkat nasional. Masalah yang dihadapi selama ini adalah beragamnya bahasa daerah sehingga sulit dindonesiakan. Walaupun begitu, hal itu dapat diatasi dengan mengembalikan prinsip penamaan itu dalam tata nama geografi.

Pembahasan dalam artikel ini lebih diarahkan pada nama geografi berbahasa Indonesia-dalam hal tertentu daapat pula disandingkan dalam bahasa daerah yang mendekati kata bahasa Indonesianya, seperti Muarobungo yang dapat ditemukan pula penulisannya Muarabunga. Itu pun lebih dititikberatkan pada nama generik yang menjadi nama gabungan dalam nama spesifik.

Pembicaraan tetntang nama geografi pernah dilakukan, seperti Santoso (1993), Sandy (1994), Ruskhan (1998) dan (2003), Rais (2009) dan (Tanpa Tahun), serta Keputusan Presiden No. 112/ 2006.

Santoso (1993) membahas atruran-aturan pemberian nama geografi di Indonesia. Ataruan itu dihimpun dalam Panduan Pembakuan NamaNama Geografi. Di dalamnya dikemukakan upaya 
pembakuan nama-nama geografi Indonesia yang memperlihatkan nama-nama yang berlaku di daerah masing-masing. Penamaan itu menghasilkan adanya upaya pembakuan dengan mempertimbangkan kekhasan di daerah masing-masing.

Sandy (1994) pernah menulis artikel "Masalah-Masalah Nama Geografi" dalam antologi yang disunting Maskun Iskandar dan Atmakusumah Astraatmadja. Di dalam tulisannya, ia mengemukaan berbagai persoalan yang timbul dari nama-nama geografi, seperti nama-nama yang bercirikan kedaerahan, penulisannya, dan upaya pembakuaannya.

Ruskhan (1998) dalam majalah Kebudayaan, edisi 14, Tahun VII pernah menulis artikel yang berjudul "Penggunaan Bahasa Indonesia dalam Nama Geografi". Tulisan itu berbicara tentang berbagai penggunaan bahasa daerah dalam nama geografi. Ada beberapa tawaran yang dikemukakan dalam nama geografi, yaitu pemanfaatan kosakata bahasa Indonesia dan bahasa daerah, pertimbangan ejaan, penerjemahan, penerimaan sepenuhnya karena keinternasionalan, dan pertimbangan strukturnya.

Selanjutnya, Ruskhan (2003) menulis makalah dalam Forum Bahasa Media Massa dengan judul "Ihwal Nama Geografi di Indonesia". Makalah itu menekan berbaga persoalan yang ditemukan dalam nama-nama geografi, di samping berbahasa Indonesia ada pula nama geografi yang nama daerah dan bahasa asing. Maraknya muncul nama-nama properti yang berbahasa asing menjadi persoalan yang perlu dicarikan jalan keluarnya. Pengindonesiaan melalui penerjemahan dan penyerapan adalah alternatif yang diberikan.

Selanjutnya, pada tahun 2006 Presiden mengeluarkan Peraturan Presiden Nomor 112 Tahun 2006 tentang Tim Nasional Pembakuan Nama Rupabumi. Di dalam peraturan itu, dimuat upaya dan tujuan pembakuan nama rupabumi (geografi) dan

Rais (2009) sebagai Ketua Tim Pembakuan Nama Geografi Nasional memberikan prinsip dan prosedur penamaan geografi. Prinsip, antara lain, penggunaan abjad Romawi, penggunaan nama lokal, penggunaan bahasa Indonesia atau bahasa daerah, dan paling banyak tiga kata.
Selain itu, Rais (tanpa tahun) pernah menulis makalah "Arti Penting Penamaan Unsur Geografik, Definisi, Kriteria, dan Peranan PBB dalam Toponimi: Kasus Nama-Nama Pulau di Indonesia". Di dalam makalahnya, Rais membicarakan pengertian nama unsur georafi dan kriteria penamaan geografi. Di samping itu, dikemukakan pula peranan Perserikatan Bangsa-Bangsa dalam nama-nama unsur geografi. Ada dua organisasi PBB yang menangani penamaan unsur geografi, yaitu United Nations Group of Experts on Geographical Names (UNGEGN) dan United Nations Conference on Standardization of Geographical Names (UNCSGN).

Beberapa resolusi organisasi itu tentang penamaan dan standardisasi unsur-unsur nama geografi dikemukakan dalam makalah itu. Hal itu dikaitkan pula dengan upaya standardi-sasi nama geografi di Indonesia.

Untuk memahami lebih lanjut keunikan nama geografi Indonesia, berikut ini dikemukakan beberapa masalah yaitu: 1) Bagaimana keunikan nama geografi Indonesia?; 2) Unsur apa saja yang menyebabkan nama geografi Indonesia itu unik?; dan 3) Apa saja cakupan unsur geografi di Indonesia yang unik itu?

Mengingat beragam dan uniknya penamaan geografi di Indonesia, tujuan kajian ini memberikan gambaran dan analisis tentang: 1 ) keunikan nama-nama geografi di Indonesia; 2) unsur generik dan spesifik nama georafi di Indonesia; dan 3) cakupan nama-nama geografi di Indonesia.

\section{Kajian Literatur Landasan Teoretis}

Nama merupakan kata untuk menyebutkan atau memanggil orang (tempat, binatang, dan sebagainya) (Sugono, 2008). Terkait dengan nama geografi berarti kita harus berbicara tentang kata sebagai satuan yang mewakili konsep yang ingin disampaikan (dalam hal ini nama geografi itu).

De Saussure (1974) mengajukan konsep signe ( $\operatorname{sign}=$ tanda) untuk menunjukkan gabungan signifie (signinified) 'yang dijelaskan' dan signifiant (signifier) 'yang menjelaskan'. Signifie (yang dijelaskan) yang dimaksukan itu tidak lain adalah makna atau konsep dari signifient (yang menjelaskan) yang wujudnya adalah bunyi-bunyi bahasa. Baik signifie maupun signifient merupakan 
signe linguistique sebagai satu kesatuan yang merujuk kepada satu acuan berupa benda atau hal-hala lain yang berada di luar bahasa. Jadi, signifie dalam keonteks ini adalah makna, sedangkan signifient adalah satuan linguistik berupa kata. Jika kita mengambil contoh nama gografi sesuai dengan konsep yang diajukanya, misalnya, Medan dan Bukittinggi. Keduanya adalah nama yang berwujud kata yang tentu memiliki makna sebagai konsep yang ingin diwakili kata Medan dan Bukittingi.

Selain itu, kata menurut Sapir (1921) mewakili suatu konsep tunggal atau suatu kombinasi konsep yang saling berhubungan sedemikian rupa sehingga membentuk kesatuan psikologis. Dengan begitu, kata menjadi lambang dari konsep yang dapat berupa kat tungal atau gabungan dari beberapa kata yang memili acuan tertentu. Karena itu, contoh Medan dan Bukittingi merupakan kata, baik satu kata seperti Medan, maupun kombinasi kata, seperti Bukittingi. Masingmasing mewakili konsep berupa makna yang melekat pada nama itu

Lyons (1977) menjelaskan bahwa nama sebagai mana yang digunakan dalam setiap perilaku bahasa memiliki dua fungsi khusus, yakni fungsi referensial dan fungsi vokatif. Fungsi referensial berkaitan dengan hubungan referen dengan bentuk bahasa yang dipakai untuk mewakilinya. Sementara itu, fungsi vokatif merupakan fungsi yang digunakan untuk menarik perhatian seseorang dari apa yang disebut atau dipanggil. Dalam konteks nama georgafi, nama yang diberikan mengandung fungsi referensial yang dapat dilihat dari nama-nama yang pemberian masyarakat terhadap tempat yang berkaitan dengan referennya. Di samping itu, nama geografi itu yang berfungsi vokatif tampak bahwa nama itu akan membangkitkan perhatian orang terhadap panggilan suatu tempat, baik nama penampakan alam, nama buatan, maupun nama adminstratif yang diberikan.

Jika kita menganalisis nama geografi, tentu tidak lepas dari kata yang satuan-satuan bahasa yang terdapat dari nama itu. Masing-masing memiliki unsur generik dan unsur spesifiknya, seperti yang dikemukakan oleh Rais (tanpa tahun). Unsur generiknya terdapat dari untuk yang melekat sebagai nama, seperti pulau, laut, gunung, bukit, teluk, tanjung atau terkait dengan wilayah seperti provinsi, kabupaten, kota, kecamatan, atau desa. Begitu pula, sebuah nama geografi adakalanya unsur generik dapat menjadi unsur spesifik, seperti Pulogadung, Gunungsitoli, Bukittinggi, dan Kotabaru. Jadi, pulo, gunung, bukit, atau kota sebagai unsur generik menjadi bagian dari spesifiknya.

Dalam hubungan itu, unsur generik dari suatu nama geografi adalah kata yang mngandung makna umumnya, sedangkan yang spesifik adalah kata yang mengandung makna yang membatasinya sebagai suatu kekhususan dari generiknya. Karena itu, nama geografi generiknya berkaitan dengan penampakan alam, baik daratan maupun perairan, serta buatan dan administratif, sementara spesifiknya adalah nama yang diberikan untuk tempat (Rais, 2009).

Bentuk kenampakan alam meliputi, antara lain, pulau (pulo), gunung, bukit, laut, gunung, dan teluk pada Pulau Sumatra, Bukit Barisan, Laut Jawa, Gunung Merapi, dan Teluk Tomini. yang terdiri atas unsur generik pulau, laut, gunung, kota, dan kampung sebagai unsur generik dan Sumatra, Barisan, Jawa, Merapi, dan Tomini sebagai unsur spesifiknya. Sementara itu, bentuk perairan, antara lain, adalah sungai/kali,/batang, ci, muara, dan rawa pada Sungai Kapuas, Kali Brantas, dan Muara Padang. Sementara itu, nama kawasan, buatan, administratif meliputi yang terkait dengan nama kawasan, nama yang dibangun manusia, dan administrasi pemerintahan. Mengingat nama generik dapat saja terdapat pada unsur geografinya dan adakalanya terdapat dalam nama geografi yang menjadi spsifiknya. Walaupun begitu, segi-segi nama generik yang menjadi unsur dalam nama spesifik akan menjadi fokus pembahasan.

Selanjutnya, suatu nama geografi adakalanya terdiri atas satu, dua kata, atau lebih. Masing-masing ditandai dengan adanya unsur generik dan unsur spesifik. Jika nama geografi itu hanya satu kata, unsur generiknya dapat saja implisit, seperti Bogor. Unsur generik yang implisit itu adalah, Misalnya Kota Bogor atau Kabupaten Bogor. Kota dan kapupaten merupakan unsur generiknya, sedangkan Bogor merupakan unsur spesifiknya. Begitu seterusnya dengan nama geografi yang terdiri atas dua kata atau lebih. 


\section{Generik berupa Kenampakan Alam}

Tidak semua nama kenampakan alam dibicarakan dalam pembahasan ini. Yang disinggung adalah hal-hal yang berkaitan dengan nama generik yang berpotensi menjadi nama pembentuk gabungan kata yang menghasilkan nama spesifik, antara lain, sebagai berikut.

\section{Pulo/Pulau}

Pulau/pulo merupakan nama generik. Misalnya, Pulau Sumatra, Pulau Bangka, Pulau Tarakan, dan Pulau Bali. Nama generik itu digunakan sebagai generik dalam nama geografi. Lazimnya, nama itu dikuti oleh kata sebagai spesifiknya. Namun, nama generiknya dapat bergabung dengan nama spesifik sehingga membentuk nama spesifik geografi. Misalnya, Pulaupanjang, Pulogadung, Pulogebang, Pulomas, dan Pulosari. Sebagai nama spesifiknya, ada adjektiva dan nomina. Nama terakhir seperti panjang, gadung, gebang, mas, dan sari memiliki makna tertentu berkaitan dengan generiknya. Panjang boleh jadi struktur daerah-nya berbentuk pulau yang memanjang. Begitu pula penambahan kata panjang, gadung, gebang, mas, dan sari berkemungkinan memiliki kaitan dengan kata generiknya.

\section{Gunung dan Bukit}

Nama gunung dan bukit ditemukan juga dalam nama geografi yang menjadi nama generik geografi, seperti Gunung Singgalang, Gunung Slamet, dan Bukit Barisan. Nama generik itu dapat pula membentuk nama geografi yang bermakna spesifik. Misalnya, Gunungsitoli, Gunungkidul, Gunungtua, Gunungmas, Bukittinggi, Bukitcangang, Bukitapit, Bukitdago, Bukitlawang, dan Bukitsari. Baik gunung maupun bukit ada yang dikuti oleh adjektiva seperti Gunungkidul, Gunungtua, dan Bukittinggi dan ada pula yang diikuti oleh nomina seperti Gunungmas, Bukitdago, Bukitlawang, dan Bukitsari, Selain itu, ada yang diikuti oleh verba, seperti Bukitcangang dan Bukitapit.

Kembali kepada nama spesifik yang mengikuti generiknya, tentu ada kaitan makna yang dapat diungkap. Nama kidul (selatan) dan tinggi berkaitan dengan posisi kota itu. Sementara itu, nama tua merupakan penamaan terhadap usia tempat itu.

\section{Tanjung}

Nama tanjung sebagai nama generik dalam geografi, misalnya, Tanjung Cina dan Tanjung Api. Nama generik dapat bergabung dengan nama spesifik yang membentuk nama geografi yang spesifik. Misalnya, Tanjungpriok, Tanjungpinang, Tanjungpura, Tanjungmas, Tanjungperak, Tanjung-pandan, Tanjungpasir, dan Tanjungbarat. Dalam contoh itu nama generik tanjung diikuti oleh nama spesifik berupa nomina. Nama spesifik yang mengikuti generiknya memiliki makna yang dapat dirunut. Baik bentuk tanjung maupun kandungan tumbuhan yang ada akan menghasilkan nama spesifiknya. Tanjungpriok ada kemungkinan bentuknya seperti periuk; Tanjungpinang dan Tanjungpandan kemungkinan daerah itu ditumbuhi oleh pohon pinang dan pandan. Sementara itu, Tanjungperak, Tanjungmas, dan Tanjungpasir memiliki kandungan perak (dapat juga penghasil), mas, dan pasir. Tanjungbarat berkaitan dengan arah tempat itu sebelah barat.

\section{Padang}

Nama generik berupa padang dalam bahasa Indonesia sebagai nama generik geografi jarang ditemukan. Misdalnya, dalam nama geografi di luar Indonesia ditemukan Padang Gobi dan Padang Sahara. Namun, nama generik padang itu dapat bergabung sebagai pembentuk nama spesifik banyak ditemukan. Misalnya, Padangpanjang, Padangluar, Padangjapang, Padangsidempuan, Padanglaweh, Padangpasir, Padangsibusuk, Padangkandih, dan Padangbaru. Nama generik padang diikuti oleh nomina seperti japang, sidempuan, pasir, sibusuk, dan kandih serta adjektiva seperti panjang, laweh, dan baru.

Penamaan nama generik dengan spesifik itu tidak lepas dari makna yang terkandung dalam nama itu. Padangpanjang, Padanglaweh, Padangbaru mengandung makna padang berbentuk panjang, luas, dan lebih baru dari yang lain. Padang luar bisa jadi posisinya sebelah luar dari posisi Kota Bukittinggi. Bagaimana dengan Padangjapang, Padangsidempuan, Padangpasir, Padangsibusuk, Padangkandih? Padangjapang adalah padang tempat orang Jepang pada pendudukan Jepang bermarkas; Padangsidempuan, Padansibusuk, dan Padangkandih ada kaitan dengan kondisi tempat itu. Misalnya, Padangsibusuk dan 
Padangkandih banyak ditumbuhi oleh pohon sibusuk dan kadih.

\section{Generik berupa Perairan}

Perairan, antara lain, meliputi sungai/kali/batang, ci, muara, dan rawa. Nama itu menjadi generik dalam nama geografi.

\section{Sungai, Kali, Batang, Ci-}

Nama generik sungai, kali, batang, dan ci- banyak ditemukan dalam nama-nama geografi. Penggunaannya mencirikan kekhasan di daerah tertentu. Nama sungai digunakan secara umum, seperti Sungai Musi, Sungai Kapuas, dan Sungai Mahakam. Nama generik sungai dapat pula membentuk nama geografi yang bersifat spesifik, misalnya, Sungaipenuh, Sungailiat, Sungaibatang, Sungaitanang, Sungailandai, Sungaibaru, Sungaiduri, dan Sungaipuar.

Selanjutnya, nama kali lebih banyak digunakan di Pulau Jawa, misalnya, Kali Berantas, Kali Kresek, dan Kali Malang (sebagai nama kali). Nama generik kali sebagai salah satu pembentuk nama geografi yang bersifat spesifik, seperti Kalideres, Kalimalang (nama tempat), Kalipasir, Kalijodoh, Kaliurang, Kalibaru, Kalibata, Kalimas, dan Kalisari. Sementara itu, nama batang digunakan di Sumatra bagian tengah yang bersinonim dengan sungai. Misalnya, Batang Hari, Batang Antokan, Batang Sianok, dan Batang Tambuo. Nama batang sebagai nama generik terdapat pula pada nama geografi yang membentuk nama spesifik. Misalnya, Batangkandis, Batangsariak, dan Batangkapeh. Namun, nama batang itu dapat juga berhomonim dengan batang 'pohon'.

Nama ci banyak sekali ditemukaan di daerah Jakarta, Jawa Barat, dan Banten, misalnya, Ci Tarum, Ci Manuk, dan Ci Sadane. Nama generik ci sangat potensial menjadi nama pembentuk nama geografi seperti nama kota, kecamatan, dan desa. Misalnya, Cibadak, Cimacan, Cilandak, Cibiru, Cibereum, Cikoneng, Cipanas, Cipete, Cimanggis, Cinangka, Cisalak, Cipayung, Ciranjang, Cipaku, Cianjur, Cisaat, dan Cileduk, Jika diungkap, nama spesifik yang mengikuti nama generik itu bervariasi, misalnya, ada nama fauna badak, macan, dan landak; ada juga warna: biru, bereum ('merah'), dan koneng ('kuning'); ada pula jenis flora: anjur, peta (petai) manggis, nangka, dan salak; terdapat juga nama benda: payung, ranjang, paku; ada juga sifat air: panas, saat ('kering'), dan leduk ('kotor'); dan sebagainya.

\section{Muara}

Nama generik berupa muara (muaro) dapat ditemukan pada nama geografi seperti Muara Padang. Nama generik itu dapat membentuk nama spesifik geografi, seperti Muaraangke, Muarabatu, Muaraenim, Muarakarang, Muaramahat, Muarasi-pongi, Muarateweh, dan Muarobungo. Nama generik muara/muaro diikuti oleh nama spesifiknya berupa nomina angke, batu, enim, karang, mahat, sipongi, teweh, dan bungo (bunga) yang menghasilkan nama spesifik tempat. Nama spesifik yang mengikutinya memiliki kaitan nama dengan nama generik yang dinamai.

\section{Rawa}

Nama rawa sebagai nama generik umumnya ditemukan di Jakarta. Namun, nama itu sebagai nama geografi menjadi nama pembentuk nama spesifik geografi. Misalnya, Rawamangun, Rawabunga, Rawabuaya, Rawebadak, Rawakambing, Rawabelong, Rawaseneng, Rawabening, Rawakemiri, Rawamelati, dan Rawakebembem. Nama generik itu diikuti oleh nama spesifik nomina seperti mangun, bunga, buaya, badak, kambing, kemiri, melati, dan kebembem serta adjektiva belong, seneng, dan bening. Nama generik nomina terdiri atas nomina flora seperti mangun, bunga, kemiri, melati, dan kebembem serta fauna seperti buaya, badak, dan kambing. Ada kemungkinan nama spesifik itu menunjukkan terjadinya pada masa dahulu "tempo doeloe" dalam sejarah Jakarta.

\section{Lubuk}

Nama lubuk yang berarti 'bagian yang dalam dari sungai (laut, danau, dansebaginya) atau jeluk' sebagai unsur generik dalam nama geografi dapat ditemukan di Indonesia. Misalnya, Lubukbasung, Lubukmatakucing, Lubukminturun, Lukbagaluang, dan Lubuklinggau, Penggunaan nama generik lubuk ditemukan di Sumatra Barat dan Sumatra Selatan. Sementara itu, unsur spesifiknya: basung, mata kucing, minturun, bagalung, dan linggau tampak-nya mengandung makna nama pohon/ bagian kayu, binatang, kemiripan, dan bentuk. 
Makna pohon adalah basung dan linggau; binatang adalah minturun; kemiripan adalah mata kucing, yakni lubuk yang mirip mata kucing; bentuk adalah bagalung (bergelung).

\section{Generik berupa Nama Buatan}

Nama buatan dalam nama ggeografi adalah nama yang dibangun, diolah, dan dikelola manusia yang muncul belakangan, misalnya, pusat belanja, pertanian, dan hunian.

\section{Generik berupa Pusat Belanja}

Ada beberapa pusat belanja tradisional yang dilambangkan dengan kata pasar, pekan, dan balai (dalam bahasa Minangkabau). Nama itu merupakan generik yang terdapat dalam nama geografi. Misalnya, Pasarahad, Pasarminggu, Pasarsenen, Pasarrebo, Pasarkemis, Pasarjumat, Pasarbaru,Pasarusang, Pasarsenggol, dan Pasarular. Di samping itu, penggunaan pekan (pakan) terdapat sepeti pada Pekanbaru, Pakansenayan, Pakansalasa, Pakanrabaa, dan Pakankamih. Sementara itu, balai digunakan pada contoh Balaisalasa, Balaikambang, dan Balaimansiro. Baik pasar, pekan, maupun balai merupakan generik dari spesifik yang mengikutinya. Akhirnya, nama generik itu bergabung dengan spesifiknya menghasilkan nama kota, desa, atau kampung dalam geografi Indonesia.

Perkembangan pusat belanja modern akhirakhir ini makin pesat. Munculnya mal, pasarswalayan, dan toserba mendatangkan kemudahan bagi masyarakat pembeli. Karena itu, bermunculan pula nama-nama pusat belanja modern, misalnya, Mal Ciputra, Mal Kelapagading, dan Pasarswalayan Ramayana. Walaupun begitu, nama generik pasar modern belum potensial membentuk nama spesifik seperti halnya pasar, pekan, dan balai.

\section{Generik berupa Hunian}

Hunian dapat saja berupa pondok, hotel, vila, grama, sangraloka. Hunian itu merupakan generik dalam nama yang membentuk nama hunian. Misalnya, Pondokindah, Pondokpinang, Pondokkopi Pondokbambu. Gryakencana, Griyaloka, Griyalestari, Hotel Indonesia, Hotel Aston, Vila Melati, Vila Pamulang, Grama Palma, Grama Sumberpalma, Sanggraloka Tira, dan Sanggraloka
Tebing Bali,

Nama hunian itu pada dasarnya terdiri atas generik yang dapat menjadi spesifik setelah bergabung dengan nama berikutnya. Perlu dicatat bahwa munculnya berbagai nama untuk hunian disebabkan adanya pemadanan kata asing ke dalam bahasa Indonesia. Vila, dukuh, dan grama dari villa/village, sanggraloka dari resort.

Tampaknya ada nama generik yang dapat membentuk nama spesifik seperti Pondokindah, Pondokpinang, Pondokkopi, Pondokbambu, Pondokacang. Namun, beberapa di antaranya tidak dapat membentuk nama spesifik, seperti vila, hotel, grama, dan sanggraloka. Karena itu, penulisannya tetap dipisah antara nama generik dan spesifiknya.

\section{Generik berupa Lahan Tanam}

Nama generik berupa lahan tanam adalah kebun/ kebon/parak/ladang dan taman. Nama generik kebun/kebon/parak dapat ditemukan, misalnya, pada Kebonjeruk, Kebonkacang, Kebonkelapa, Kebonmanggis, Kebonsirih, Parakkarambia, Parakkarakah, Paraklaweh, Paraktinga, Ladanglaweh, dan Ladangtibarau. Karena sifat kebun/kebon/ parak/ladang sebagai lahan pertanian, nama spesifiknya adalah flora seperti jeruk, kacang, kelapa, manggis, sirih, karabia (kerambil), karakah, dan tibarau. Namun, ada juga yang bermakna ukuran, yakni laweh (luas) pada Paraklaweh dan Ladanglaweh. Sementara itu, ada juga verba seperti tinggal (tinggal).

Nama generik taman dapat dijumpai dalam contoh Tamanmelati, Tamankota, Tamansari, Tamanmenteng, Tamanlawang, Tamananggrek, Tamanpuring. Tampaknya nama spesifik umumnya nama bunga, seperti melati, sari, menteng, lawang, anggrek, dan puring. Namun, ada juga yang berupa kawasan, yakni kota pada Tamankota. Nama-nama yang unsur generiknya taman ditemukan di Jakarta.

\section{Generik berupa Nama Administratif}

Ada dua nama administrati yang melekat pada nama geografi, yakni kota dan kampung, misalnya, Kota Tangerang dan Kota Bogor serta Kampung Ciputat dan Kampung Pondokserut (di Ciledug). Nama generic itu dapat berfungsi sebagai namapembentuk nama spesifik. Misalnya, nama 
kota adalah Kotabaru, Kotabumi, Kotacane, Kotabunga, Kotagede, Kotanopan, dan Kotapinang. Nama spesifiknya ada yang adjektiva seperti baru dan gede. Sementara itu, nama spesifik berupa nomina, misalnya, bumi, cane, bunga, nopan, dan pinang.

Sementara itu, nama generik berupa kampung dapat ditemukan seprti pada Kampungambon, Kampungmelayu, Kampungjawa, Kampungnaga, Kampungrambutan, Kampungasam, Kampungmadura, dan Kampungmakasar. Unsar spesifiknya adalah nomina etnis, seperti Ambon, Melayu, Jawa, Madura, dan Makassar serta nomina flora/fauna seperti rambutan, asam, dan naga.

Ada juga unsur generik berupa kota dan koto di beberapa daerah di Indonesia. Unsur kota, misanya, Kotabaru (Sumatra, Kalimantan), Kotacane (Aceh), dan Kotanopan (Sumatra Utara). Sementara itu, koto banyak ditemukan di Sumatra Barat, seperti Kototinggi, Kototuo, Kotopanalok, Kototangah, Kotogadang, dan Kotomarapak.

\section{Simpulan dan Saran Simpulan}

Nama-nama geografi di Indonesia memiliki keberagaman. Nama-nama geografi itu ada yang menggunakan bahasa Indonesia dan di samping menggunakan bahasa daerah. Keragaman itu merupakan keunikan Indonesia yang kaya dengan etnis dan budayanya, termasuk bahasa.

Jika di lihat dari unsurnya, nama geografi terdiri atas nama generik dan nama spesifik. Nama generik merupakan nama yang berlaku secara umum, baik berupa nama kenampakan alam, buatan, kawasan, dan administratif. Namanama generik itu berpotensi dalam bahasa Indonesia-termasuk bahasa daerah-menjadi nama spesifik. Dengan kata lain, nama spesifik dibentuk dari nama generik dan spesifik. Walaupun begitu, ada kemungkinan nama spesifik itu berupa nama generik dan nama generik.

Nama yang diciptakan masyarakat tidak lepas dari sejarah penamaannya. Ada kalanya penamaan dengan nama generik itu merupakan penandaan terhadap sesuatu yang ada pada nama generiknya. Misalnya, tempat yang banyak ditumbuhi oleh tanaman di rawa, pondok atau kebun (kebon) atau memiliki bentuk dan posisi tertentu.

Penamaan geografi dapat dilakukan dengan menggabungkan nama generik, baik berupa kenampakan alam, perairan, kawasan, maupun buatan. Segi kenampakan alam lebih potensial daripada yang lain. Penamaan itu terdapat dalam nama geografi seperti kota, kecamatan, desa, dan kampung.

\section{Saran}

Berkaitan dengan simpulan di atas, ada beberapa saran yang menjadi perhatian penulis sebagai berikut. Pertama, Nama geografi yang begitu unik di Indonesia perlu mempertimbangkan penggunaan bahasa Indonesia, tetapi tidak mengabaikan penggunaan bahasa daerah jika mengan-dung nilai kesejarahan, Kedua: 2) Pembakuan nama geografi di Indonesia perlu dilakukan di setiap daerah dengan mengikuti aturan penamaan yang bersifal nasional.: 3) Nama generik dapat dikembangkan oleh pihak yang diberi wewenang, baik di pusat maupun di daerah, untuk memberi nama baru nama georgafi yang belum bernama atau mengganti nama georgafi yang tidak sesui dengan prinsip dan kriteria yang diatur.

\section{Pustaka Acuan}

Keputusan Presiden Nomor 112 Tahun 2006 Tentang Tim Nasional Pembakuan Nama Rupabumi. Merriam-Webster. 1993. Merriam Webster's Collegiate Dictionary. Edisi 10. Springfield: MerriamWebster.

Pateda, Mansur. 2001. Semantik Leksikal. Jakarta: Reneka Cipta.

Rais, Jacob. Tanpa Tahun. "Arti Penting Penamaan Unsur Geogfrafik, Definisi, Kriteria, dan Peranan PBB dalam Toponomi: Kasus Nama-Nama Pulau di Indonesia". Bogor: Bakosurtanal.

Rais, Jacob. 2009. "Pembakuan Penulisan Nama Geografi di Indonesia". Bogor: Bakosurtanal. Ruskhan, Abdul Gaffar. 1998. "Penggunaan Bahasa Indonesia dalam Nama Geografi". Dalam Kebudayaan, 14. (Tahun VII). Jakarta: Departemen Pendidikan dan Kebudayaan. 
Ruskhan: 2003. "Ihwal Nama Geografi di Indonesia". Makalah dalam Forum Media Massa di Jakarta, 5 Juni 2003. Jakarta.

Sandy, I Made. 1994. "Masalah-Masalah Nama Geografi". Dalam Maskun Iskandar dan Atmakusumah Astraatmadja (Penyunting) "Masalah Bahasa dan Nama Geografi dalam Pers Indonesia Masa Kini". Jakarta: Lembaga Pers Dr. Soetomo.

Santoso, Widodo Edy (Penyunting). 1993. "Panduan Pembakuan Nama-Nama Geografis". Jakarta: Bogor: Panitia Tetap Nasional Nama-Nama Geografis.

Sapir, Edward. 1921. Language: Introduction to the Study of Speech.

Saussure, Ferdinand de. 1974. Course in General Linguistics. New York: Mc Graw-Hill Book Company. Sugono, Dendy, Sugiyno, dan Meity Taqdir Qudratillah. 2008. Kamus Besar Bahasa Indonesia Pusat Bahasa. Jakarta: Gramedia Pustaka Utama. 